\title{
Family Policy in the United States: State-Level Variation in Policy and Poverty Outcomes from 1980 to 2015
}

\author{
Zachary Parolin and Rosa Daiger von Gleichen
}

The 50 United States have long featured vast differences in their levels of support for low-income families. As far back as 1939, the generosity of social assistance transfers as part of the Aid to Dependent Children program ranged from an average monthly allowance of $\$ 2.50$ for a mother in Arkansas to $\$ 24.50$ for a mother in New York (Cauthen \& Amenta, 1996). Recent evidence suggests that state-level family policy divergence has continued, and perhaps intensified, in more recent decades (Bruch, Meyers, \& Gornick, 2016). In the mid-1990s, the federal government granted increasing administrative authority to the states with respect to cash assistance for vulnerable families (Page \& Larner, 1997). In the two decades following, many states would increasingly exert control over social and labor market policies, ratifying state-level increases in the statutory minimum wage, supplements to federally administered refundable tax credits, work-preparation programs, childcare subsidies, and even paid sick and family leave policies.

This chapter investigates the diversity of states' family policy packages from two perspectives. First, we detail the variance of states' policies as they relate to three key dimensions of family policy packages: money, services, and time. For each dimension, we document the extent of state-level variance in recent

Z. Parolin (凶)

Columbia University, New York, NY, USA

e-mail: Zachary.parolin@columbia.edu

R. Daiger von Gleichen

Department of Social Policy and Intervention, University of Oxford, Oxford, UK e-mail: rosa.vongleichen@stx.ox.ac.uk 
years and, when possible, highlight convergence or divergence in the family policy indicators over time. If states are increasingly diversifying with respect to family policy packages, we might similarly expect that social outcomes for families with children are also diverging. This is the second focus of our chapter. Specifically, we provide descriptive evidence on trends in state-level variance in six social outcomes: (1) child poverty rates after accounting for taxes and transfers, (2) child poverty rates while only accounting for market income, (3) the male-to-female employment ratio, (4) the male-to-female earnings ratio, (5) out-of-pocket medical expenditures among households with children, and (6) expenditures on childcare among households with children. While this is of course not an exhaustive list of family-related outcomes, it should nonetheless provide an idea of whether states are moving farther apart not only in terms of family policy packages, but also in terms of family economic outcomes.

Our primary findings confirm that family policy packages vary widely across the 50 states, and that this is increasingly true with respect to the coverage of cash assistance for low-income families, statutory minimum wage levels, and healthcare coverage. However, this divergence in policies has not always translated into divergence in social outcomes. We find that state-level variation in post-tax/transfer child poverty rates, for example, has remained stable over time despite growing variance in many of states' family-oriented policies. On the other hand, we find clear evidence that some states' decisions to expand Medicaid coverage has contributed to state-level variation in outof-pocket medical spending. We conclude this chapter with a discussion on why state-level family policy variation often does not translate into variation in social outcomes.

\section{Background}

\section{Family Policy Across the $\mathbf{5 0}$ United States}

Family policy encompasses a vast scope of policies, which some scholars have argued should include all measures that affect "the family" (Kamerman \& Kahn, 1979; Kaufmann, 1993). Kamerman and Kahn distinguish between "explicit" and "implicit" family policies. Whether or not they aim at a specified goal, explicit family policies "deliberately do things to and for the family" whereas implicit family policies are not "specifically or primarily addressed to the family, but $[\ldots]$ have indirect consequences" for families. Given these (in)direct effects, Kamerman and Kahn (1981) highlight the necessity to 
examine the family policy "package", i.e., the combination of policies that create the policy context for families. Their framework to capture a holistic family policy package distinguishes between family policies providing (1) money, (2) services, and/or (3) time (Kamerman \& Kahn, 1994). Money ostensibly provides the choice as to whether family members with care obligations can provide care themselves or purchase care-services instead, although the practical reality of this depends greatly on the generosity level of the monetary benefit. Services provide care-enabling family members to continue active employment. Time policies give family members the option of performing care themselves.

Compared to other advanced democracies, the United States invests very little in "money, time, and services" for families (Daiger von Gleichen \& Seeleib-Kaiser, 2018). As O’Connor, Orloff, and Shaver (1999, p. 223) highlight, the state "is clearly subordinate to the market and the family" in the United States when it comes to ensuring the financial security of families with children. Indeed, the primacy of the market is easily identified across all three dimensions of money, services, and time. However, the extent to which this is true varies across the 50 states. As noted in the Introduction, of this Volume, recent studies suggest that states have increasingly diverged with respect to the provision of family-oriented policies. Before getting into detail of trends in state-level variation, we first highlight the core elements of the family policy package across the 50 states. In Table 18.1, we break down the primary family-oriented policies into their money, services, and time dimensions. We focus primarily on specific policies or programs over which state governments, rather than the federal government, have some authority.

Importantly, this is not an exhaustive list of policies that might affect families with children. The United States features many in-kind or near-cash benefits, for example, that are important to the wellbeing of families, but that tend to be funded on the federal level. The Supplemental Nutrition Assistance Program (SNAP, or "food stamps") is a good example: though technically administered by the states, its benefit calculation procedures are set at the federal level, and all benefit allocations are funded by the federal government. Moreover, the benefits are not exclusively available to families with children. As such, we do not feature SNAP prominently in our discussion of state-level family policy variation.

Table 18.1 does include medical services, which in many countries do not qualify as explicit family policies. Here the United States is an exception. The two healthcare services are explicitly geared toward the family, as the rhetoric that circumscribes them is of aiding families in meeting the substantial healthcare costs in the United States (Centers for Medicare and Medicaid Services, 2018). 
Table 18.1 Family policy package in the United States

\begin{tabular}{|c|c|c|c|}
\hline Dimension & Name & Eligibility & $\begin{array}{l}\text { Federal or state } \\
\text { funding }\end{array}$ \\
\hline \multirow[t]{2}{*}{ Money } & $\begin{array}{l}\text { Temporary } \\
\text { Assistance to } \\
\text { Needy Families } \\
\text { (TANF) }\end{array}$ & $\begin{array}{l}\text { Means-tested, } \\
\text { time-limited }\end{array}$ & $\begin{array}{l}\text { Federal Block Grant, } \\
\text { supplemented by } \\
\text { the states }\end{array}$ \\
\hline & $\begin{array}{l}\text { Earned Income } \\
\text { Tax Credit (EITC) }\end{array}$ & $\begin{array}{l}\text { Means-tested, } \\
\text { employment-related }\end{array}$ & $\begin{array}{l}\text { Federal EITC funded } \\
\text { federally, State EITC } \\
\text { funded by the } \\
\text { states }\end{array}$ \\
\hline \multirow[t]{2}{*}{$\begin{array}{l}\text { Services } \\
\text { (childcare) }\end{array}$} & Pre-Kindergarten & $\begin{array}{l}\text { Age and residency } \\
\text { restrictions }\end{array}$ & Funded by the states \\
\hline & Head-Start & Means-tested & Federally funded \\
\hline \multirow[t]{2}{*}{$\begin{array}{l}\text { Services } \\
\text { (healthcare) }\end{array}$} & $\begin{array}{l}\text { Children's Health } \\
\text { Insurance Program } \\
\text { (CHIP) }\end{array}$ & $\begin{array}{l}\text { Means-tested, age } \\
\text { restrictions }\end{array}$ & $\begin{array}{l}\text { Federal block grant, } \\
\text { supplemented by } \\
\text { the states }\end{array}$ \\
\hline & Medicaid & Means-tested & $\begin{array}{l}\text { Federal block grant, } \\
\text { supplemented by } \\
\text { the states }\end{array}$ \\
\hline Time & $\begin{array}{l}\text { State Family Leave } \\
\text { Programs }\end{array}$ & Employment-related & State funded \\
\hline
\end{tabular}

\section{Money, Services, and Time Across the 50 United States}

With the conceptual structure of the family policy package in place, we now provide an overview of the policies relating to "money, services, and time" across the 50 United States. Specifically, we provide details relating to eight programs or services that state governments in the United States have some authority to control and that relate to the financial security of families with children. Later, we will demonstrate trends in state-level variation in the eight programs and services to detail how states have diverged (or converged) over time with respect to each dimension.

Money: Temporary Assistance for Needy Families (TANF), the Earned Income Tax Credit (EITC), and statutory minimum wages form the core of the "money" dimension of the American family policy package.

TANF is the country's primary cash-based social assistance program and is primarily targeted at single-mother families. It was introduced in the mid1990s as a replacement for the less restrictive Aid to Families with Dependent Children (AFDC) program. The legislation that introduced TANF transformed three core components of state-administered social assistance. First, it strengthened the conditionality requirements attached to the receipt of cash assistance. Under AFDC, families under a certain income threshold were entitled to cash support. With the introduction of TANF, however, that 
entitlement was ended and recipients would be required to engage in "work participation activities" or employment to continue receiving cash support beyond a certain duration (Falk, 2014). Second, the legislation expanded the scope of the program's objectives. While AFDC was primarily a cash assistance program, states can allocate TANF funds toward any of the program's four statutory purposes: "to provide assistance to needy families," "to end the dependence of needy parents on government benefits by promoting job preparation, work, and marriage," "to prevent and reduce the incidence of out-of-wedlock pregnancies," and "to encourage the formation and maintenance of two-parent families" (Parolin, 2019). Third, TANF introduced a "block grant" funding scheme, effectively providing states with a fixed sum of money to manage their own TANF programs. Today, all states spend less on cash assistance under TANF than they did in the late 1990s. Ten states, in fact, spend less than $10 \%$ of their TANF block grants on cash assistance, instead allocating the funds toward efforts to encourage work, promote two-parent families, or other miscellaneous expenditures.

The federal EITC is effectively a subsidy for low-wage earners. Though it does not exclusively target families with children, the value of the wage subsidy increases with the number of children in the household. Though the federal EITC was introduced in 1975, it was strengthened considerably throughout the 1990s. Beginning with Wisconsin in the mid-1980s, some states have introduced their own supplements to the federal EITC. By 2015, 23 states offered state-level supplements to the federal EITC, compared to just eight states in 1994 (Internal Revenue Service, 2015).

Finally, statutory minimum wages simply act as the wage floor for employed workers. The federal government sets a minimum wage level that applies across all states, but state governments have increasingly acted to raise the wage floor beyond the federal minimum. In 2014, 22 states offered statutory minimum wage levels higher than the federal minimum, compared to only five such states in 1994 (U.S. Department of Labor, 2015). Though not an explicit family-oriented policy, the level of the minimum wage certainly has an effect on the financial security of low-income families. Different from SNAP, minimum wage levels are set by state governments and vary considerably across the 50 states. Thus, we include minimum wages in our analysis of state-level variation over time.

Services: Early childhood education, childcare, and healthcare programs are the core of our analysis of family-oriented services. Pre-Kindergarten ("Pre-K") programs provide care and education support for 3- and 4-year olds. These are mostly supported by state funds, with the explicit intent to support working families with young children (National Institute for Early 
Education Research, 2015). Greater investment into pre-K increases the odds that a parent with young children can, if desired, secure childcare support and enter the labor market. Pre-K programs exist in addition to (and usually completely separately from) the federal, targeted Head-Start programs that are nearly entirely federally funded. Forty-one states had such pre-K programs in 2014.

The specific health insurance policies examined are Medicaid and the (State) Children's Health Insurance Program (commonly abbreviated to (S)CHIP). Unlike the general federal health insurance Medicare which is funded and administered federally, Medicaid and (S)CHIP are administered by the states under federal guidelines and funded by states with "matching" federal funds of at least $50 \%$. While both Medicaid and (S)CHIP are meanstested, the difference is that (S)CHIP is intended to insure those children whose parents' income exceeds the maximum eligibility for Medicaid but who are still unable to afford private healthcare insurance for their children (Finegold, 2005; Meyers, Gornick, \& Peck, 2001). In this sense, both Medicaid and (S)CHIP are addressed to the entire family, aiding its members to meet the financial burden of providing healthcare for children. After passage of the Patient Protection and Affordable Care Act in 2010, states were granted the option to expand Medicaid eligibility to individuals with annual incomes below $138 \%$ of the federal poverty level (rather than at a lower income threshold). States expanding Medicaid receive additional financial support from the federal government for doing so. A state's prioritization of Medicaid and CHIP protects low-income families against income shocks in the event of health concerns, and allows families to receive medical treatment without relying on an employer or family member for health insurance coverage.

Time: The United States is an outlier among advanced democracies in not providing a paid parental leave program at the federal level. Instead, the country features the Family and Medical Leave Act (FMLA), which mandates 12 weeks of unpaid leave for family or medical purposes. In Chapter 17 in this volume, Cassandra Engeman explores state-level unpaid leave policies that expand on the framework set by the FMLA. In recent years, several states have further introduced their own paid leave programs. Engeman's chapter describes these and temporary disability insurance programs that can provide wage replacement benefits during leave in the previous chapter. Here, we focus on paid leave programs and discuss them in greater detail later in this chapter during our analysis of cross-state divergence. 


\section{Divergence in Policies, Divergence in Outcomes?}

The mid-1990s marked a turning point in the governance of family-oriented policies in the United States The introduction of TANF was at the core of a broader movement to shift authority over social programs from the federal to the state government. This era of decentralization premised that each state, rather than the federal government, ought to be able to more effectively serve the interests of its constituents and thus, should have greater discretion over the allocation of public resources (Meyers et al., 2001, p. 459; Obinger, Leibfied, \& Castles, 2005). Some scholars referred to this era as a "devolution revolution" (Nathan \& Gais, 2001), or a turn from centralized social programs to more devolved, state-led programs. One potential benefit of greater devolution was that state diversity in programs would create natural experiments, building an evidence base of which policy changes to a given program might be most beneficial for improving families' economic security.

In the two decades following the onset of this "devolution revolution", several comparative analyses have sought to understand the extent of statelevel variation in social policies. Studies have demonstrated, for example, that state governments vary widely with respect to labor relations (Hays, 1954), healthcare (Collins, Felderhoff, Kim, Mengo, \& Pillai, 2014) and education policy (McLendon \& Perna, 2014). With respect to family-oriented policies, Meyers et al. (2001) similarly found that the 50 states feature much diversity in the generosity of their policy packages for families with young children.

Other studies have sought to understand whether states have become more diverse over time with respect to social and family policies. Bruch et al. (2016) find the diversity of states' social policies has generally widened from 1994 to 2014 , in line with claims of a "devolution revolution" after welfare reform. Conducting a latent-variable analysis of 148 state-level policies across eight decades, for example, Caughey and Warshaw (2016) find that variation in states' "policy liberalism" - a measure of leftward ideological orientation-has steadily increased from 1936 to 2014.

Despite evidence of state-level policy divergence, however, less is known about whether state-level social outcomes for families with children have similarly diverged. Given that state-level policies affect the economic wellbeing of households within the state, and that family-oriented policies have appeared to diverge at the state level, then we might similarly expect to observe a divergence in social outcomes among families living in different states. In this chapter, we look at state-level variance in six indicators of family economic wellbeing that family policies typically aim to address. These include indicators of child poverty (both before and after transfer are 
included), male-female gaps in employment and earnings, and average family spending on medical and childcare expenses. We do not attempt to isolate the effect of individual policies on the outcomes. First, we expect that each of the family policies affect our outcomes of interest in some way. For example, greater provision of pre- $\mathrm{K}$ should have consequences for each of the indicators: insofar as pre-K allows a mother to enter the labor force, it can have an effect on the male-to-female employment and earnings gap, and may similarly affect levels of child poverty. If a working mother can more easily access healthcare coverage, then out-of-pocket medical spending may decline, as well. Second, our interest in this chapter is documenting descriptive trends rather than identifying the causal effects of state-level policies. Thus, we will observe whether state-level trends in the variation of family policies align with trends in the variation of family-related social outcomes.

\section{Data and Methods}

Our primary analysis is concerned with measuring the relative variation of states' family policy inputs and social outcomes over time. We measure convergence or divergence using the coefficient of variation $(\mathrm{CV})$, a simple measure of dispersion commonly applied in descriptive studies of policy convergence. The $\mathrm{CV}$ is calculated as the standard deviation of a set of indicators relative to its mean in a given year. For example, to measure the $\mathrm{CV}$ of states' maximum TANF benefits in a given year, we simply divide the standard deviation of states' maximum TANF levels relative to the unweighted mean of states' maximum TANF levels. When the CV declines for a given indicator over time, this indicates that states are becoming more similar with respect to the indicator (less variance), and a rising $\mathrm{CV}$ over time indicates divergence in the set of indicators (more variance). In sensitivity checks, we also estimate convergence measuring the 90th percentile of a state's value for a set of indicators relative to the 10th percentile, but we find no substantive difference in the trends of the two measures. For simplicity, then, we only show changes over time in the $\mathrm{CV}$.

In Table 18.2, we present details on how we construct each of our policy indicators and social outcome variables. For each of the three indicators in the benefits and wages dimension, we have data that span many years (19802015) and thus can produce a reliable estimate of convergence or divergence over time. For other indicators, such as state spending on pre-Kindergarten 
Table 18.2 Measurement of family policy indicators and social outcomes

\begin{tabular}{|c|c|c|}
\hline Policy name & Generosity indicator & Coverage indicator \\
\hline EITC & State match of federal EITC & $\begin{array}{l}\text { Share of eligible earners } \\
\text { claiming EITC }\end{array}$ \\
\hline Minimum Wage & $\begin{array}{l}\text { Level of state statutory } \\
\text { minimum wage }\end{array}$ & $\mathrm{n} / \mathrm{a}$ \\
\hline TANF & $\begin{array}{l}\text { Maximum benefit level for } \\
\text { family of three }\end{array}$ & $\begin{array}{l}\text { Share of families in } \\
\text { poverty receiving TANF } \\
\text { benefits }\end{array}$ \\
\hline \multicolumn{3}{|l|}{ Service name } \\
\hline Pre-Kindergarten & Spending per enrolled child & $\begin{array}{l}\text { Percent of enrolled 3- } \\
\text { and 4- year olds, out of } \\
\text { all 3- and 4-year olds in } \\
\text { the state }\end{array}$ \\
\hline Medicaid/CHIP & $\begin{array}{l}\text { Federal }+ \text { state spending on } \\
\text { CHIP and Medicaid per } \\
\text { enrolled child }\end{array}$ & $\begin{array}{l}\text { Ratio of eligible/enrolled } \\
\text { children to all eligible } \\
\text { children }\end{array}$ \\
\hline Social outcome & \multicolumn{2}{|l|}{ Definition } \\
\hline $\begin{array}{l}\text { Child poverty rates } \\
\text { (market income, } \\
\text { post-tax/transfer) }\end{array}$ & \multicolumn{2}{|c|}{$\begin{array}{l}\text { Share of children in the state and year with income } \\
\text { below } 50 \% \text { of national equivalized median } \\
\text { household income }\end{array}$} \\
\hline $\begin{array}{l}\text { Male-to-female } \\
\text { employment ratio }\end{array}$ & \multicolumn{2}{|c|}{$\begin{array}{l}\text { Ratio of male employment rate (age } 18-65 \text { ) in } \\
\text { state-year to female employment rate in state-year }\end{array}$} \\
\hline $\begin{array}{l}\text { Male-to-female } \\
\text { earnings ratio }\end{array}$ & \multicolumn{2}{|c|}{$\begin{array}{l}\text { Ratio of median annual market earnings of all } \\
\text { employed men relative to the median earnings of all } \\
\text { employed women in state-year }\end{array}$} \\
\hline $\begin{array}{l}\text { Out-of-pocket medical } \\
\text { expenditures }\end{array}$ & \multicolumn{2}{|c|}{$\begin{array}{l}\text { Dollar value of out-of-pocket medical expenditures for } \\
\text { average family in state-year }\end{array}$} \\
\hline $\begin{array}{l}\text { Work and childcare } \\
\text { expenses }\end{array}$ & \multicolumn{2}{|c|}{$\begin{array}{l}\text { Dollar value of work and childcare expenditures for } \\
\text { average family in state-year }\end{array}$} \\
\hline
\end{tabular}

Note Data sources are listed in appendix Table 18.8

programs, we only have cross-sectional data in a recent year. For such indicators, we describe differences in states' levels of investment, but cannot say much about changes in variance over time.

For our five policies of interest, we include indicators of both generosity and coverage. Generosity reflects the level of the given benefit in real terms or, in the case of the two services, state spending on the given service relative to the number of children in the states. Coverage, meanwhile, represents the number of potentially eligible individuals who actually utilize the given benefit or service. For TANF, for example, we measure coverage as the share of families in poverty in the given state and year who actually receive TANF benefits. Lower coverage thus not necessarily indicates less demand for the given policy or service; instead, it may indicate that the benefit or service is simply less accessible for families in the given state and year. With respect to 
TANF, for example, many states have imposed strict work requirement, drug tests, and short lifetime time limits that inhibit many low-income families from accessing the benefits. In such states, coverage of TANF will be lower.

Data on our six social indicators come from the U.S. Current Population Survey (CPS ASEC). For our two measures of child poverty (pre-tax/transfer and post-tax/transfer), we follow the common practice in international poverty literature in setting the poverty threshold at $50 \%$ of the national household median income. ${ }^{1}$ Our post-tax/transfer measure also follows the common practice of including all taxes and transfers (even near-cash benefits such as "food stamps") into the income definition.

We measure the male-to-female employment ratio as the average employment rate of men in a given state-year relative to the average employment rate of women in the state-year. With respect to the male-to-female earnings ratio, we measure the median annual market earnings of employed men relative to the median earnings of employed women. Finally, we measure outof-pocket medical expenditures and work and childcare expenses as the mean level of expenditure among households with children in a given state-year. Before measuring the mean, we top-code levels of expenditure at the 99th percentile in each year.

\section{Diversity in State-Level Family Policy Packages}

We first present results on the diversity and divergence of the money, services, and time dimensions of states' family policy packages. We then present the descriptive trends in our outcomes of family economic wellbeing.

Money-Table 18.3 shows the cross-state diversity in the generosity and coverage of TANF, state EITC supplements, and statutory minimum wages in 2015. The bottom rows of Table 18.3 also show the change in average values of the indicators from 1980 to 2015 .

As described in the prior section, the coefficient of variation, presented in the middle row of Table 18.3, describes the relative disparity of states' family policy indicators for 2015. With respect to the generosity of TANF, EITC, and the minimum wage, variation is clearly greatest in the state EITCs (CV of 1.38). This is primarily because nearly half the states offer no state-level supplement to the EITC. Variation is smaller for the maximum TANF benefit

\footnotetext{
${ }^{1}$ An alternative approach would have been to set the poverty threshold at $60 \%$ of national household median income, as is standard in the European Union and much of the social policy literature. In this approach, levels of poverty increase slightly, but trends in variation across states are not meaningfully affected.
} 
Table 18.3 State-level diversity in generosity and coverage of 'money' dimension of family policy in 2015

\begin{tabular}{|c|c|c|c|c|c|}
\hline & \multicolumn{3}{|l|}{ Generosity } & \multicolumn{2}{|c|}{ Coverage } \\
\hline & TANF & State EITC & Minimum wage & TANF & EITC \\
\hline 10th percentile & $\$ 262$ & 0 & $\$ 7.25$ & $6.9 \%$ & $76.0 \%$ \\
\hline Median & $\$ 429$ & 0.03 & $\$ 7.75$ & $19.7 \%$ & $80.0 \%$ \\
\hline Mean & $\$ 443.8$ & 0.08 & $\$ 7.95$ & $22.7 \%$ & $79.5 \%$ \\
\hline 90th percentile & $\$ 640$ & 0.25 & $\$ 9$ & $39.9 \%$ & $82.5 \%$ \\
\hline St. Dev. & $\$ 170.44$ & 0.11 & $\$ 0.79$ & $15.0 \%$ & $2.7 \%$ \\
\hline Coeff. of variation & .384 & 1.38 & .099 & .662 & .034 \\
\hline Mean, 1980 & $\$ 761.88$ & 0.00 & $\$ 7.94$ & - & - \\
\hline Mean, 2015 & $\$ 443.80$ & 0.08 & $\$ 7.95$ & - & - \\
\hline Change (p.p.) & $-\$ 318.08$ & 0.08 & $\$ 0.01$ & - & - \\
\hline
\end{tabular}

Note Unweighted state-level statistics. Generosity of EITC refers to share of federal EITC that state government matches. Coverage of TANF refers to share of households in poverty receiving TANF benefits in the state in 2015. Coverage of EITC refers to share of eligible households collecting federal or state EITC benefits in the year. Mean dollar values in 1980 presented in real 2015 USD using PCE deflator

values (CV of .384), but the gap between the 10th and 90th percentiles remains notable: a difference in $\$ 380$ per month in benefit levels. From 1980 to 2015 , the mean level of maximum TANF benefits declined more than $\$ 300$ in real terms. The minimum wage shows the smallest variance of the three indicators (CV of .099), primarily because the federal minimum wage floor ensures that nearly half the states have the same minimum wage of $\$ 7.25$ per hour. From 1980 to 2015, there was virtually no change in the mean value of states' wage floors (in real terms).

In the right half of the table, coverage rates for TANF and the EITC are presented. Recall that the EITC coverage rates refer to participation in either the federal or state EITC in 2015 (among eligible households). Thus, even states with no state-level EITC supplement will have positive values of EITC participation. Here, we see that variation in coverage of TANF (CV of .662) far exceeds that of the EITC (CV of .034\%). Note that variation in TANF coverage is nearly double the variation observed in maximum benefit levels in the left half of Table 18.3.

We now turn toward an assessment of variation over time for the generosity of AFDC/TANF, state supplements to the EITC, and the minimum wage. In Fig. 18.1, we display trends in the CV. State EITC supplements are unique among the three in seeing strong convergence over time (the downward sloping gray line in Fig. 18.1). Recall that in the mid-1980s, only one state (Wisconsin) featured a supplement to the federal EITC. Today, however, nearly half the states offer a bonus to low-income workers collecting 


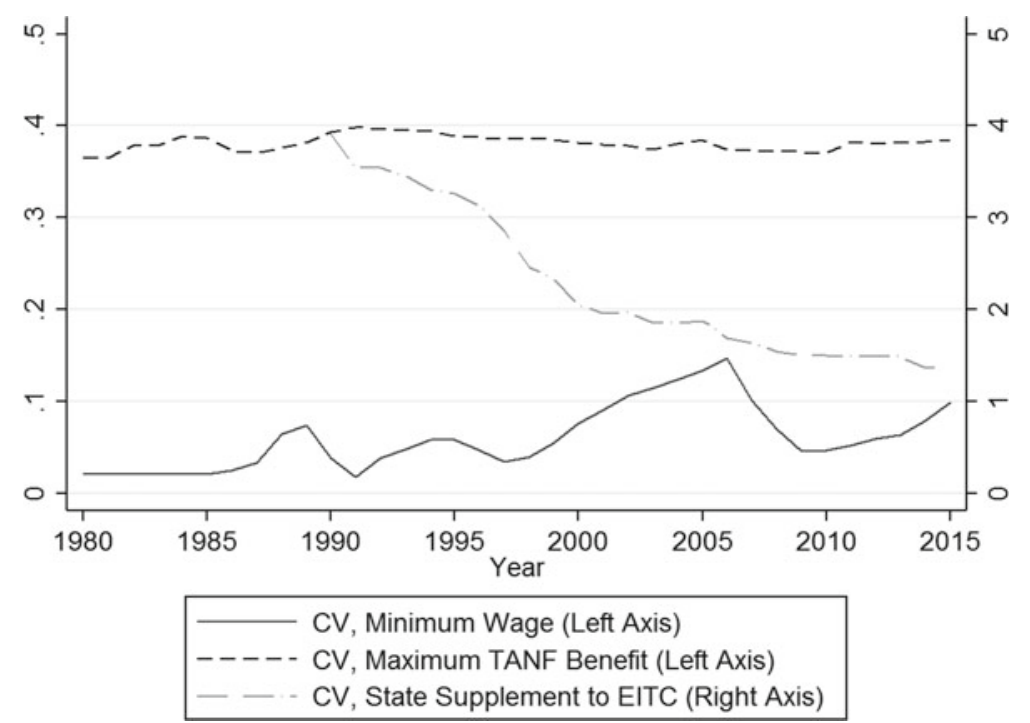

Fig. 18.1 Change in variation of state-level wage and benefit policies

the federal EITC. The state additions to the federal EITC vary: in New Jersey, low-wage workers can claim an extra $35 \%$ of the total value of their federal EITC. Like most states offering an EITC supplement, New Jersey offers a refundable credit, meaning that if a household's tax credits exceed their tax liabilities, they can collect the negative balance as cash. In a few states (Delaware and Virginia, for example), the state EITC supplements are non-refundable.

Unlike the EITC, states' statutory minimum wages have diverged over time (the solid black line shifting upward in Fig. 18.1). They have further seen ebbs and flows in terms of their similarity: when the federal government orders a minimum wage increase, such as in 2009 , state similarity naturally increases. From 2009 onward, however, the upward sloping line in Fig. 18.1 represents decisions from many state governments to lift their wage floor above the federal minimum. Though the time series presented in this paper ends in 2015, the divergence has only continued in recent years. In April 2016, two of the largest United States-California and New York-ratified legislation that would, over time, increase the statutory minimum wage for non-tipped workers to $\$ 15$ per hour. Pending an increase in the federal minimum wage (set at $\$ 7.25$ per hour since 2009 ) prior to the full phase-in of the two states' new laws, the shift will mark the first time in modern American history when statutory minimum wage levels in a particular state will more than double the federal standard (U.S. Department of Labor, 2015). 
Variation in maximum benefit values of AFDC/TANF, however, have remained relatively stable from 1980 onward. Despite "welfare reform" in the mid-1990s, states have not diverged in terms of the benefit levels offered to low-income families. Of course, this is not to say that states are not diverse in terms of their benefit levels. We saw in Table 18.3 that states vary widely, and that mean benefit values are declining over time. As the figure shows, however, these differences have been relatively stable throughout the "devolution revolution." Later, we return to the question of how variation in coverage of AFDC/TANF over time might also shape state-level social outcomes.

Services-Unlike for our "money" measures, we only have data on (S)CHIP and pre-K spending and coverage for recent years. Thus, we do not present the trends in the $\mathrm{CV}$, as we do for the prior three policies. Table 18.4 presents state-level variation in the indicators in 2015. As discussed before, generosity of pre-K refers to spending per enrolled child, and generosity of Medicaid/CHIP refers to federal and state spending on CHIP and Medicaid per enrolled child. We measure coverage, respectively, as the share of all 3and 4-year-olds enrolled in a state pre-K program and the share of eligible children enrolled in Medicaid/CHIP.

As Table 18.4 suggests, state-level variation in pre-Kindergarten is greater, both in generosity and coverage, than state-level variation in Medicaid/CHIP in 2015. Variation in state-spending on pre-K (CV of .819) more than doubles that of spending on Medicaid/CHP (CV of .344). This is in part because only 41 states offered pre-K programs in 2014, whereas Medicaid exists in all states. Though we do not have longitudinal data on pre-K and Medicaid/CHIP spending, we can point to recent state-level expansions of Medicaid as one potential source of state-level divergence. After the passage of

Table 18.4 State-level diversity in generosity and coverage of services dimension of family policy package in 2015

\begin{tabular}{llcccc}
\hline & \multicolumn{2}{l}{ Generosity } & & & \multicolumn{2}{c}{ Coverage } \\
\cline { 2 - 3 } \cline { 5 - 6 } \cline { 5 - 6 } & Pre-K & Medicaid/CHIP & & Pre-K & Medicaid/CHIP \\
\hline 10th percentile & 0 & $\$ 8271$ & & $0.0 \%$ & $87.6 \%$ \\
Median & $\$ 3671$ & $\$ 12,973$ & & $11.5 \%$ & $93.7 \%$ \\
Mean & $\$ 3888$ & $\$ 13,314$ & & $15.0 \%$ & $92.6 \%$ \\
90th percentile & $\$ 8074$ & $\$ 19,284$ & & $40.6 \%$ & $96.2 \%$ \\
St. Dev. & $\$ 3183.62$ & $\$ 4585$ & & $16.4 \%$ & $3.7 \%$ \\
Coeff. of variation & .819 & .344 & & 1.09 & .040 \\
\hline
\end{tabular}

Note Generosity of Pre-K refers to spending per enrolled child. Generosity of Medicaid/CHIP refers to federal and state spending on CHIP and Medicaid per enrolled child. Coverage of Pre-K refers to share of 3- and 4-year-olds enrolled. Coverage of Medicaid/CHIP refers to share of eligible children enrolled 
the Affordable Care Act in 2010, states governments were granted the option to expand Medicaid access to people with annual incomes below $138 \%$ of the federal poverty level. Most of the additional funding for the program would be covered by the federal government. At time of writing, 36 states and Washington, DC, have expanded Medicaid access, while 14 states have held out. We see from Table 18.1 that there is much diversity in state-level Medicaid spending per child, as well as in coverage rates of eligible children. Given the expansion of Medicaid in the 36 states that have accepted it, we may see an increase in state-level diversity in terms of how much the average family spends out-of-pocket on medical expenses. We return to this possibility when evaluating trends in social indicators of family wellbeing in the next section.

Time-The unavailability of paid family or parental leave is a well-noted shortcoming of U.S. family policy. As noted before, the federal government ensures only 12 weeks of unpaid family or medical leave for employed adults (with additional tenure requirements, employer criteria and contract type restrictions). As of 2015, only three states offered their own paid family leave plans beyond disability compensation for the birth mother: California, New Jersey, and Rhode Island. New York implemented a paid family leave program in 2018, and Washington will join the fold in 2020 (for details on the development of these and other leave policies, see Chapter 17 by Engeman, in this volume). Further, the generosity and duration of the benefit among these early adopting states is quite modest. In 2015, California paid family leave was capped at 55\% income replacement, and available for six weeks. In New Jersey, the cap was set at two-thirds of wages, also for six weeks. Rhode Island provided paid family leave for four weeks with a cap of $\$ 752$ per week (National Conference of State Legislatures, 2016). As three states had implemented paid family leave by 2015 , divergence in the "time" dimension of family policy has technically occurred since 1980 . However, given the small number of adopting states combined with the modest duration of coverage, this divergence has perhaps not been large enough to make a meaningful difference in variance of state-level social outcomes.

\section{Diversity in Social Outcomes}

We now examine levels and trends in state-level variation of the six familyrelated social outcomes. We first look at our two measures of child poverty: market income and post-tax/transfer poverty. Table 18.5 presents the diversity of states' child poverty rates in 2015 . The average state had a market income child poverty rate of $35.3 \%$ in 2015 , but with a range from 27.1 to $44.3 \%$ 
Table 18.5 State-level diversity in child poverty outcomes in 2015

\begin{tabular}{lcc}
\hline & Market income poverty & Post-transfer poverty \\
\hline 10th Percentile & $27.1 \%$ & $16.2 \%$ \\
Median & $35.1 \%$ & $21.5 \%$ \\
Mean & $35.3 \%$ & $22.4 \%$ \\
90th Percentile & $44.3 \%$ & $30.6 \%$ \\
St. Dev. & $7.0 \%$ & $6.0 \%$ \\
Coeff. of variation & .200 & .268 \\
Mean, 1980 & $30.2 \%$ & $24.4 \%$ \\
Mean, 2015 & $35.3 \%$ & $22.4 \%$ \\
Change (p.p.) & $5.1 \%$ & $-2.0 \%$ \\
\hline
\end{tabular}

Note Market income poverty refers to poverty rates before taxes and transfers are included

when jumping from the 10th percentile to 90th percentile to state. From 1980 to 2015, states' mean value of market income poverty rates increased by more than 5 percentage points.

Interestingly, the diversity between states grows when bringing taxes and transfers into measures of household income. As the right half of Table 18.5 shows, the mean state featured a post-tax/transfer poverty rate of $22.4 \%$ in 2015. The poverty rate in the 90th percentile state (30.6\%) nearly doubled that of the 10th percentile state (16.2\%). From 1980 to 2015, states' mean value of post-tax, post-transfer poverty rates declined by 2 percentage points. That average post-tax, post-transfer poverty rates declined while marketincome poverty rates increased suggests that taxes and transfers have played an increasingly important role in reducing levels of poverty.

The coefficient of variation is also larger for post-tax/transfer poverty rates, indicating that states are more diverse in their poverty rates after taxes and transfers are taken into account. How has this diversity changed over time? Figure 18.2 displays trends in the coefficient variation for both measures of child poverty: post-tax/transfer (solid line) and pre-tax/transfer (dashed line). We highlight three observations from this figure. First, state-level variance in market income poverty tends to be consistently lower than post-tax/transfer poverty-not just in 2015, as we saw in the prior table. Second, state-level variance in market income poverty has declined over time (as have overall rates of market poverty). Third, despite the convergence in market income poverty, we see relative stability in state-level variation in post-tax/transfer poverty. Insofar as the "devolution revolution" has contributed to more diversity in state-level family policies, it has not appeared to translate into rising variance in post-tax/transfer poverty rates. 


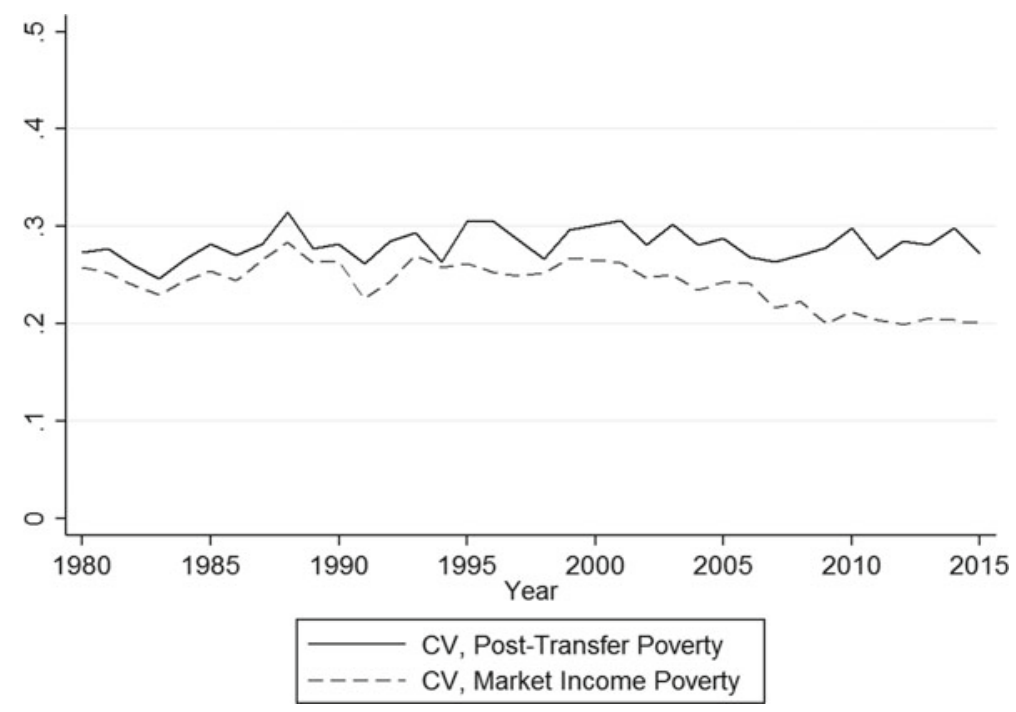

Fig. 18.2 Change in variation of states' pre- and post-tax/transfer poverty rates (Note Poverty threshold set at $50 \%$ of national equivalized median household income. Data U.S. current population survey. $\mathrm{CV}=$ coefficient of variation)

One potential reason for a decline in variation in market income poverty rates is a decline in variation of male-to-female employment and earnings gaps. Table 18.6 presents the diversity of the two measures in 2015. Looking at the male-to-female employment ratio, we see that male adult employment is larger than female adult employment in all states. However, the extent of the gap varies meaningfully: in the 10th percentile state, the gap is a mere 1.12 , meaning that male employment is $12 \%$ higher than female employment. In the 90th percentile state, the gap is 1.37 . With respect to median earnings of males compared to the median earnings of females

Table 18.6 State-level diversity in male-to-female employment and earnings outcomes in 2015

\begin{tabular}{lcc}
\hline & M:F employment ratio & M:F earnings ratio \\
\hline 10th percentile & 1.12 & 1.41 \\
Median & 1.23 & 1.57 \\
Mean & 1.23 & 1.62 \\
90th percentile & 1.37 & 1.88 \\
St. Dev. & 0.10 & 0.22 \\
Coeff. of variation & .080 & .134 \\
Mean, 1980 & 1.56 & 2.93 \\
Mean, 2015 & 1.23 & 1.62 \\
Change (p.p.) & -0.33 & -1.29 \\
\hline
\end{tabular}


(right side of the figure), we see even more variance. The coefficient of variation is .054 higher for the earnings gap compared to the employment gap. For the average state, the median earnings for employed men was around $57 \%$ higher than the median earning for employed women. However, the male-to-female employment and earnings gaps have declined over time, as the bottom rows of Table 18.6 point out.

Figure 18.3 shows how variation among states in these two measures has changed over time. The solid black line represents trends in the CV of statelevel male-to-female earnings gaps, while the dashed line represents the same for the employment gaps. We see that states have converged over time with respect to both indicators, but much more so for the earnings gap relative to the employment gap. Between 1980 and 2015, the CV for the earnings gap fell from around 0.25 to below 0.15 - a notable increase in convergence. This convergence in the earnings gap ratio largely reflects the rise in female educational attainment and women's larger-scale entry into managerial positions since the 1980s. However, from 1996 onward, it is also a product of the change that has taken place in U.S. family policy. Across the 50 states, the introduction of TANF has necessitated mothers with caring obligations, who under AFDC could have refrained from active labor market participation, to take low-wage employment. These earnings likely also contributed to the reduction in variance visible in the earnings gap ratio.

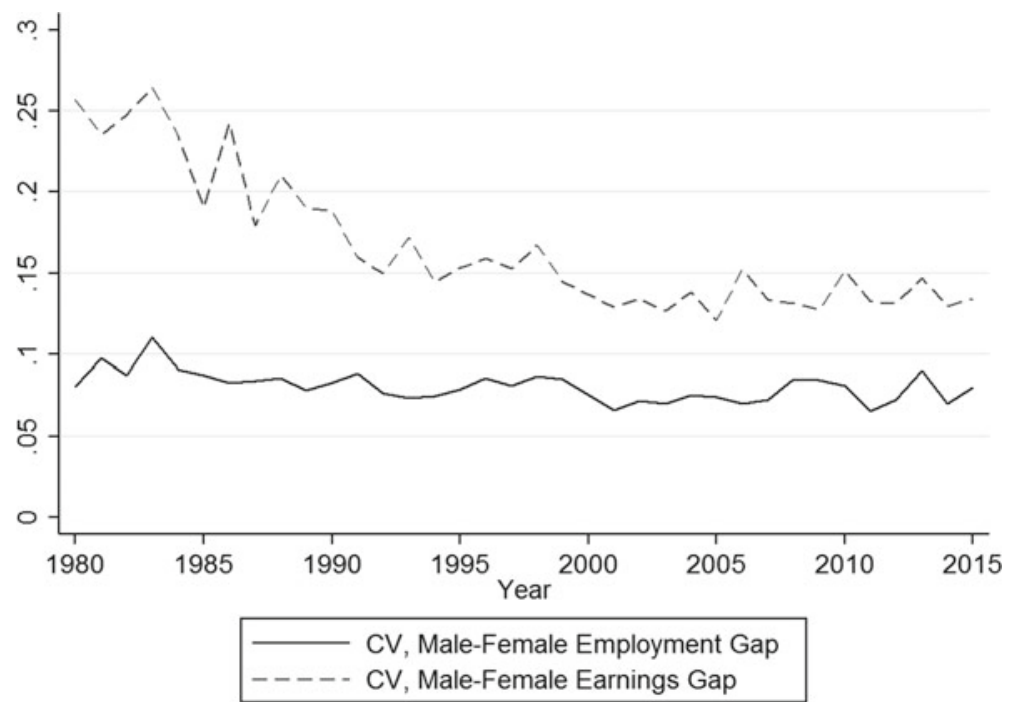

Fig. 18.3 Change in variation of states' male-female employment and earnings gaps 
Table 18.7 State-level diversity in average medical out-of-pocket and childcare expenditures in 2015

\begin{tabular}{lll}
\hline & OOP medical expenditures & $\begin{array}{l}\text { Work and childcare } \\
\text { expenditures }\end{array}$ \\
\hline 10th percentile & $\$ 3687$ & $\$ 3113$ \\
Median & $\$ 4781$ & $\$ 3542$ \\
Mean & $\$ 4870$ & $\$ 3559$ \\
90th percentile & $\$ 5818$ & $\$ 4001$ \\
St. Dev. & $\$ 711$ & $\$ 362$ \\
Coeff. of variation & .146 & .102 \\
Mean, 1980 & $\$ 2014$ & $\$ 2070$ \\
Mean, 2015 & $\$ 4870$ & $\$ 3559$ \\
Change (p.p.) & $\$ 2856$ & $\$ 1489$ \\
\hline
\end{tabular}

Note Mean dollar values in 1980 presented in real 2015 USD using PCE deflator

Finally, we can look at diversity in divergence of out-of-pocket medical spending and work and childcare expenditures for families with children. Table 18.7 presents the diversity across states in 2015 . In the average state, the average family with children spent around $\$ 4870$ out of pocket on medical expenditures in 2015. Between the 10th percentile and 90th percentile states exhibit a more than $\$ 2000$ annual difference $(\$ 3867-\$ 5818)$. For childcare expenditures, the cross-state variance is slightly smaller (10.2\%) compared to the variance for medical expenditures (14.6\%). In the average state, the average family with children spent $\$ 3559$ on childcare expenditures in 2015 . This is a steep increase from the mean values of inflation-adjusted childcare spending in 1980.

As Fig. 18.4 shows, we have seen divergence over time across states. In other words, states vary more with respect to average medical and childcare expenditures for the average family. This is particularly true for medical spending: as Fig. 18.4 demonstrates, the $\mathrm{CV}$ increases from .06 to .15 between 1980 and 2015. Most of this increase occurs around the passage of the Affordable Care Act and subsequent Medicaid expansion across many states. This pattern might be explained by the fact that states vary more in terms of the accessibility of health insurance after recent Medicaid expansion drives (more generous states have expanded Medicaid, but less generous states have not), and that Medicaid expansion should drive down out-of-pocket medical costs for low-income families, as more of these families will now have health insurance. Thus, more variance in the accessibility of Medicaid leads to more variance in out-of-pocket medical spending. From 2009 onward, cross-state variance in medical expenditures has been greater than variance in 


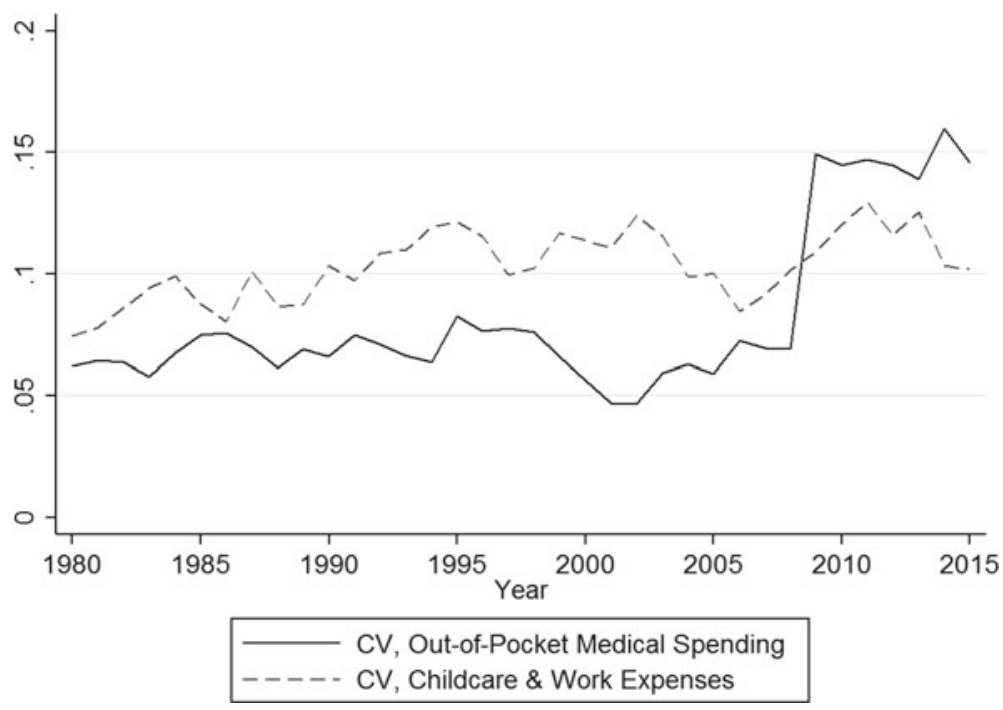

Fig. 18.4 Change in variation of states' average levels of medical and childcare expenditures among households with children

childcare expenditures. For childcare spending, we observe a rise in the CV from .07 to .10 between 1980 and 2015 .

\section{Discussion}

Trends in state-level family policies and social outcomes do not offer a straightforward narrative of divergence. With respect to our money dimension of the family policy package, we observed convergence in state supplements to the federal EITC, stability in the variance of maximum TANF cash assistance benefits, and divergence in statutory minimum wages. With respect to the services and time dimensions, we observed large variation in states' approaches to childcare support, healthcare coverage, and paid family leave time. With respect to our family-oriented social outcomes, we have not seen meaningful increases in variance in child poverty rates or female employment and earnings outcomes from 1980 onward. In fact, the male-to-female earnings gap and market income poverty rates both declined in variance over time-probably both due to the related phenomenon of rising women's educational attainment and earnings across all states over time. Conversely, state-level variance out-of-pocket medical expenditures and childcare spending has risen over time. 
These findings point to two primary conclusions and points of discussion. First, the evidence suggests that diversity, more so than divergence, is the story of state-level variation in family policy packages. As noted in the opening sentence of this chapter, states have long varied with respect to the generosity of family-oriented social assistance benefits. This remains true today. As we saw in Table 18.3, coverage and generosity of states' TANF benefits in 2015 varies widely, even if we have not seen large shifts in variance over time. Consider also the relatively stable diversity in states' child poverty outcomes. Despite large variance in child poverty rates across states (Table 18.5), we have not seen a lot of change in the cross-state variance over time.

Second, federally funded policies that also target families with children likely mitigate some of the social consequences of cross-state variance in family policy packages. Put differently, federally funded redistribution programs such as SNAP, the EITC, or Supplemental Security Income (SSI) likely "offset" some of states' differences in TANF, minimum wages, and so on. There are two primary reasons for this. First, as state-level redistributive programs (TANF, in particular) have declined in value in recent decades, federally funded transfers such as SNAP, SSI, and the EITC (for which benefit levels tend to be common across the states) have increased greatly in recent decades. Second, prior evidence suggests that when a state cuts back on the generosity of its TANF benefits, federally funded SSI and SNAP spending largely fill in the gap (Parolin \& Luigjes, 2019). We can visualize this by displaying changes in state-level variation of observed levels of household benefit receipt for the state-administered TANF benefits versus the federally funded SNAP, SSI, and EITC benefits. Figure 18.5 displays the results.

AFDC/TANF clearly stands out in Fig. 18.5: it is the only program in which state-level variance in observed benefit receipt has increased from 1980 onward. Thus, despite the stagnation in variance of maximum benefit levels, states have certainly become more diverse in terms of the level of benefits actually allocated to families with children. The three federally funded programs have seen convergence across states over time in terms of mean levels of observed benefit receipt. Put differently, states are becoming more similar in the amount of benefits received from the federally funded SNAP, SSI, and the EITC, but less similar in terms of benefits received from AFDC/TANF. Given that SNAP, SSI, and the EITC now allocate more total benefits each year than the TANF program, the convergence in states' receipt of benefits from these three programs might help explain the stability in state-level variance in poverty outcomes, as observed in Fig. 18.2. 


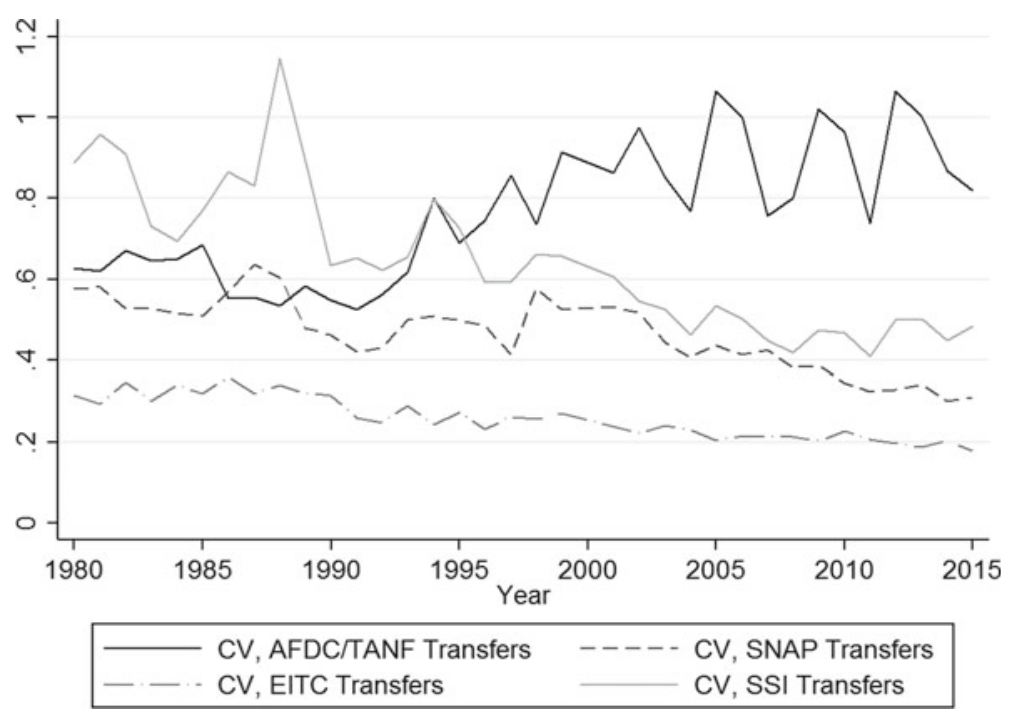

Fig. 18.5 Change in variation of states' average levels of benefit receipt among households with children

\section{Conclusion}

This chapter set out to investigate the diversity and divergence of three sets of family policy indicators across the 50 United States: money, services, and time. We first provided an overview of family policy packages in the United States. Second, we provided descriptive evidence of the diversity of states' family policy packages in cross-sectional and longitudinal perspective. Finally, we provided a descriptive portrait of trends in state-level diversity of several indicators of family wellbeing.

Our findings demonstrate that the 50 United States vary considerably in their family policy packages, particularly with respect to cash assistance for low-income families. States have become more dissimilar over time with respect to social assistance transfers and statutory minimum wages, but have become more similar in their supplements to the EITC. Moreover, states vary greatly in their levels of support for early childhood education and healthcare funding.

Do state-level trends in the variation of family policies align with trends in the variation of family-related social outcomes? We find mixed evidence that this is the case. Despite large diversity and some divergence in states' family policy packages, post-tax/transfer poverty rates have remained relatively stable over time. This is partially due to an increase in federally funded transfer programs mitigating the social consequences of state-level diversity. 
States have converged, however, in levels of market income poverty rates, a trend that appears to be related to declining variation in male-to-female employment and earnings gaps. Finally, we observed that state-level variation in out-of-pocket medical spending has more than doubled from 1980 to 2015, in large part due to some states deciding to expand Medicaid access from 2009 onward.

Acknowledgements Rosa Daiger von Gleichen acknowledges support from the United Kingdom Economic and Social Research Council and the Heinrich Böll Foundation.

\section{Appendix}

See Table 18.8 .

Table 18.8 Data source and timeframe for family policy inputs and social outcomes

\begin{tabular}{|c|c|c|c|}
\hline Dimension & Indicator & Years & Source \\
\hline Benefits & EITC generosity & 1980-2014 & $\begin{array}{l}\text { UKCPR National Welfare } \\
\text { Data }\end{array}$ \\
\hline Benefits & EITC coverage & 2014 & $\begin{array}{l}\text { UKCPR National Welfare } \\
\text { Data }\end{array}$ \\
\hline Benefits & Minimum wage & 1980-2014 & $\begin{array}{l}\text { UKCPR National Welfare } \\
\text { Data }\end{array}$ \\
\hline Benefits & TANF generosity & $1980-2014$ & $\begin{array}{l}\text { UKCPR National Welfare } \\
\text { Data }\end{array}$ \\
\hline Benefits & TANF coverage & 2014 & $\begin{array}{l}\text { Center on Budget and } \\
\text { Policy Priorities (2016) }\end{array}$ \\
\hline Services & Pre-K generosity & 2014-2015 & $\begin{array}{l}\text { National Institute for Early } \\
\text { Education Research, State } \\
\text { of Preschool Yearbook } \\
\text { 2014: State Profiles }\end{array}$ \\
\hline Services & Pre-K coverage & 2014 & $\begin{array}{l}\text { National Institute for Early } \\
\text { Education Research, State } \\
\text { of Preschool Yearbook } \\
\text { 2014: State Profiles }\end{array}$ \\
\hline Services & Medicaid/chip coverage & 2014 & $\begin{array}{l}\text { Kaiser Family Foundation, } \\
\text { State Health Facts: } \\
\text { Medicaid/CHIP Child } \\
\text { Participation Rates }\end{array}$ \\
\hline Services & Medcaid/chip spending & 2015/16 & $\begin{array}{l}\text { Kaiser Family Foundation } \\
\text { and medicaid.gov }\end{array}$ \\
\hline Time & Family leave & $2012-2015$ & \\
\hline
\end{tabular}




\section{References}

Bruch, S. K., Meyers, M. K., \& Gornick, J. C. (2016). Separate and unequal: The dimensions and consequences of safety net decentralization in the U.S. 1994-2014 (IRP Discussion Paper Series [DP 1432-16]).

Caughey, D., \& Warshaw, C. (2016). The dynamics of state policy liberalism, 19362014. American Journal of Political Science, 60(4), 899-913. https://doi.org/10. 1111/ajps.12219.

Cauthen, N. K., \& Amenta, E. (1996). Not for widows only: Institutional politics and the formative years of aid to dependent children. American Sociological Review, 61(3), 427-448. https://doi.org/10.2307/2096357.

Centers for Medicare and Medicaid Services. (2018). Medicare and medicaid research review. Centers Medicare Medicaid Serv. Centers for Medicare and Medicaid Services. Available at: https:/www.cms.gov/research-statistics-data-and-systems/ statistics-trends-and-reports/medicaremedicaidstatsupp/2013.html.

Collins, L. R., Felderhoff, B. J., Kim, Y. K., Mengo, C., \& Pillai, V. K. (2014). State-wide variation in teenage birth rates in the United States: Role of teenage birth prevention policies. International Journal of Child Adolescent Health, 7(3), 239-248.

Daiger von Gleichen, R., \& Seeleib-Kaiser, M. (2018). Family policies and the weakening of the male breadwinner model. In S. Shaver (Ed.), Handbook on gender and social policy (pp. 273-307). Cheltenham, England: Edward Elgar.

Falk, G. (2014). Temporary Assistance for Needy Families (TANF): Eligibility and benefit amounts in state TANF cash assistance programs. Congressional Research Service.

Finegold, K. (2005). The United States' federalism and its counter-factuals. In H. Obinger, S. Leibfried, \& F. G. Castles (Eds.), Federalism and the welfare state: New world and European experiences (pp. 138-178). New York, NY: Cambridge University Press.

Hays, P. R. (1954). Federalism and labor relations in the United States. University of Pennsylvania Law Review, 102(8), 959-979.

Internal Revenue Service. (2015). States and local governments with earned income tax credit. Retrieved from https://www.irs.gov/credits-deductions/individuals/earnedincome-tax-credit/states-and-local-governments-with-earned-income-tax-credit.

Kamerman, S. B., \& Kahn, A. J. (1979). Family policy: Government and families in fourteen countries. New York: Columbia University Press.

Kamerman, S. B., \& Kahn, A. J. (1981). Child care, family benefits, and working parents: A study in comparative policy. New York: Columbia University Press.

Kamerman, S. B., \& Kahn, A. J. (1994). Family policy and the under-3s: Money, services, and time in a policy package. International Social Security Review, 47(34), 31-43. 
Kaufmann, F.-X. (1993). Familienpolitik in Europa. In Bundesministerium für Familie und Senioren (Ed.), 40 Jahre Familienpolitik in Der Bundesrepublik Deutschland: Rückblick, Ausblick, Festschrift (pp. 141-167). Neuwied: Luchterhand.

McLendon, M. K., \& Perna, L. W. (2014). State policies and higher education attainment. The Annals of the American Academy of Political and Social Science, 665(1), 6-15.

Meyers, M. K., Gornick, J. C., \& Peck, L. R. (2001). Packaging support for low-income families: Policy variation across the United States. Journal of Policy Analysis and Management, 20(3), 457-483.

Nathan, R., \& Gais, T. (2001). Is devolution working? Federal and state roles in welfare. Brookings Institution Review, 19(3), 25-29.

National Conference of State Legislatures. (2016). State family and medical leave laws. http://www.ncsl.org/research/labor-and-employment/state-family-and-med ical-leave-laws.aspx.

National Institute for Early Education Research. (2015). The state of preschool 2014: State preschool yearbook. New Brunswick, NJ: National Institute for Early Education Research.

O’Connor, J., Orloff, A. S., \& Shaver, S. (1999). States, markets, families: Gender, liberalism and social policy in Australia, Canada, Great Britain and the United States. Cambridge, England: Cambridge University Press.

Obinger, H., Leibfried, S., \& Castles, F. (2005). Federalism and the welfare state: New world and European experiences. New York and Cambridge, UK: Cambridge University Press.

Page, S. B., \& Larner, M. B. (1997). Introduction to the AFDC program. The Future of Children, 7(1), 20-27.

Parolin, Z. (2019). Temporary assistance for needy families and the Black-White child poverty gap. Socio-Economic Review (Online First).

Parolin, Z., \& Luigje, C. (2019). Incentive to retrench? Investigating the interactions of state and federal social assistance programs after welfare reform. Social Service Review (Online First).

U.S. Department of Labor. (2015). Changes in basic minimum wages in non-farm employment under state law: Selected years 1968 to 2016. Accessed online: https:// www.dol.gov/whd/state/stateminwagehis.htm. 
Open Access This chapter is licensed under the terms of the Creative Commons Attribution 4.0 International License (http://creativecommons.org/licenses/by/4.0/), which permits use, sharing, adaptation, distribution and reproduction in any medium or format, as long as you give appropriate credit to the original author(s) and the source, provide a link to the Creative Commons licence and indicate if changes were made.

The images or other third party material in this chapter are included in the chapter's Creative Commons licence, unless indicated otherwise in a credit line to the material. If material is not included in the chapter's Creative Commons licence and your intended use is not permitted by statutory regulation or exceeds the permitted use, you will need to obtain permission directly from the copyright holder.

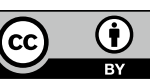

